\title{
The Investment System Reform and the Investment Efficiency of the State-Owned Enterprise: Changes and Prospects
}

\author{
Zhang Gui-ling \\ Accounting school \\ Zhengzhou Institute of Aeronautical Industry Management \\ Zhengzhou, China \\ e-mail:financepaperzhang@126.com
}

\begin{abstract}
In order to discuss whether the investment system reform improve the investment efficiency of Chinese stateowned enterprise since reform and opening-up, considering the nature and function of state-owned enterprises, the this paper constructed the investment efficiency evaluation system of statowned enterprises, with data from China Investment Yearbook and China Statistical Yearbook, this paper analyzed the investment efficiency of Chinese state-owned enterprises since 1980, and got the following conclusions, in view of the overall situation, both the micro and macro investment efficiency of the state-owned enterprise improved in past 30 years, except for the early of 1990s. The origin and new of this paper was analyzing the investment efficiency from the aspect of investment system reform.
\end{abstract}

Keywords- investment system reform; state-owned enterprise; investment efficiency; micro efficiency; macro efficiency

\section{INTRODUCTION}

The State-owned enterprises are the micro organization of state-owned economy, and according to the fifth check on state-owned assets in China, the sate-owned capital are mainly in state-owned enterprises. The investment of the sate-owned enterprise not only leads to its profit, but also affects the overall allocation efficiency of the society But the investment efficiency of the state-owned enterprise is a very controversial issue. Louis Kuijs and Bert Horfman(2006), the senior economists in China office of the World Bank, sated that the rate of return of Chinese enterprise had increased to $12.7 \%$ in 2005 from $2 \%$ in 1998; but Shan ( 2007 ) contradicted that the rate of return in Chinese industrial enterprise was not so high, and they inspired heated debate on the issue. The famous economist Xiao(2006)pointed out that what the World Bank said was macro efficiency, and the efficiency of Xiao was micro, both the two were reasonable. Liu (2007) discussed the derivation of the micro and macro investment efficiency, and pointed out that the key problem of investment in China was investment system. Since the reform and opening up in 1978, the Chinese government has promulgated and implemented more than sixty policies to reform the investment system, and has gotten remarkable achievements. In the above context, this paper was to discuss does the investment System reform improve the investment efficiency of the state-owned enterprise?

Based on the history the investment system reform, this paper analyzed the effect mechanism on investment efficiency by the reform of investment system theoretically; on the foundation of literature review on investment efficiency and the characteristics of state-owned enterprise property rights, this paper established the framework to evaluate the investment efficiency, and analyzed whether investment System reform improved the investment efficiency of the state-owned enterprise; In the end, this paper proposed some suggestions to improve the investment efficiency of the state-owned enterprise in the future.

\section{THE TRACK OF INVESTMENT SYSTEM REFORM IN CHINA}

In order to improve the efficiency of government investment, in 1979, the state council adopted the policy "change the allocation funds into loans", and this was the first step of investment system reform. Next, the implement of overall rationing system, tendering and bidding system, strengthened that enterprises were the main investment subjects. From 1984, with the deepening of the overall economic system reform, the investment system reform began to coordinate the "plan and market" in investment decisions, and the investment system reform developed in a comprehensive way. In this stage, the government gradually down the approve authority in fixed assets investment, and mainly implied the second phase of "replacement of profit by tax" policy, and fully implied "change the allocation funds into loans" policy. In 1992 the 14th National Congress of CCP established the socialistic market economy aim, and the investment system reform stepped in to the innovation stage. In this stage, the government implied a series of market 
orientation reforms, including: implied responsibility system in capital construction project, divided the scope of enterprise investment and government investment, perfected the macroeconomic control system based on industry policy, and pointed out the direction of investment system reform. In July 2004 the state council promulgated <the Decision on the Reform of the Investment System>, which was the most comprehensive and authorized policies in investment since the reform and opening up in China, marked the investment system reform stepped into the deepened stage. Up to 2004, the investment system framework suitable to social market economy had formulated primarily.

Theoretically, the diversification and decentralization of investment subjects, the normalization of investment, the multi-channel of financing and the perfect of macroeconomic control system all will improve the fixed-assets investment efficiency in state-enterprise. In addition, the owners of the state-owned enterprise are all the people in China, and the reprehensive of the people is the government, so the investment behavior of state-owned enterprise should be more sensitive to investment system reform, and the investment efficiency should improve.

\section{THE CHANGES OF STATE-OWNED ENTERPRISE INVESTMENT EFFICIENCY}

\section{A. The evaluation framework of the state-owned enterprise investment efficiency}

At present, there are many researches about the effect on the investment by the transition from planned economy to market economy. Sun (1998) researched the fixed assets investment in sate-owned department in China, and stated that the investment system and the financing mechanism didn't change, even after the reform and opening up, the significant reform in investment system in 1984 and 1994, there were not fundamental changes. Rawski ( 2002 ) criticized the Chinese investment system and investment efficiency for lower investment return and capacity surplus in large scale. Zhang (2005) regressed different types of investment on GDP, and raised that the economic reform, especially the investment system reform had fundamental influence on investment efficiency in China. But the above researches were mainly on the whole economy, the researches on the investment efficiency of state-owned enterprise were less.

The state-owned enterprise has both functions of enterprise and government, which decides its multi-aims, including micro aims and macro aims. Therefore, this paper analyzed the state-owned enterprise investment from micro and macro efficiency. The micro investment efficiency refers to the ratio of outputs to inputs, including Incremental Capital-Output Ratio (ICOR), and percentage of fixed assets being delivered for use. The macro efficiency refers to the macro allocation efficiency, including industrial efficiency and regional efficiency, namely whether the industrial and regional allocation of fixed assets are reasonable.

In summary, we construct the investment efficiency system in Fig .1.

\section{B. Micro efficiency of the state-owned enterprise investment}

1) The ICOR of the state owned enterprise investment

As we can't get the GDP of the state-owned enterprise, with reference to Zhang (2005), we substitute by the gross value of industrial output. Generally, higher ICOR means lower investment efficiency. Because of the investment delay contribution to the economy, we calculated three years moving average of ICOR. From Fig .2, we can get it is more smooth than ICOR, and overall declined since 1980s, which reflected the investment efficiency of the state-owned enterprise improved in general. But between 1990 and 1992 , the three years moving average ICOR rose. It is worth noting that since 2000 ICOR of three years moving average declined continuously, but declined slower year by year, which indicated that the investment efficiency of stateowned enterprise improved gradually but the speed was slower year by year.

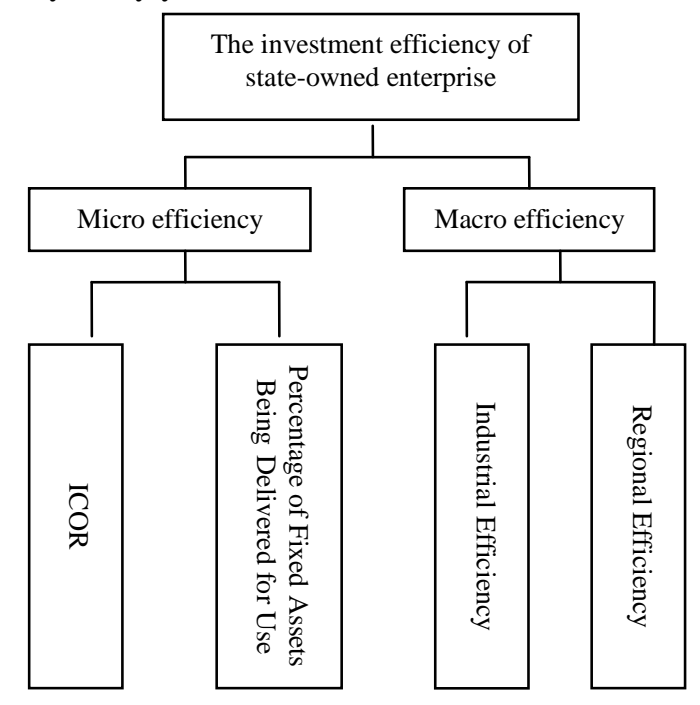

Figure 1. the evaluation framework of the state-owned enterprise investment efficiency



Figure 2. ICOR of State-owned enterprise

2) Percentage of fixed assets being delivered for use in state-owned enterprise 
Generally, higher percentage of fixed assets being delivered for use reflects better investment efficiency. 19812008, the percentage of state-owned enterprise was lower than that of private enterprise, and the average percentage was $70.4 \%$ and $84.96 \%$ respectively. 1992 1995, for stateowned enterprise, the percentage was lower, especially between 1993 and 1994, the percentage declined to 63\%. Since 1996, the rate began to rise gradually, and the percentage gap between the state-owned enterprise and private enterprise was becoming narrower. Therefore, in general, the investment efficiency of state-owned enterprise was lower than private enterprise; the investment efficiency of state-owned enterprise was improving, except for 1992 1995; and the gap between the state-owned enterprise and private enterprise was narrower gradually.

\section{Macro efficiency of the state-owned enterprise investment}

1) Industrial efficiency of the state-owned enterprise investment

According to the distribution of state-owned enterprise all over the world, the industries which the state-owned economy should control are as follows: the industries involving the nation security, natural monopoly industries, the industries providing important public goods and service and the key enterprises in high-tech industries and pillar industries. The above industries are usually considered as the valid industry for state-owned enterprise. Because of the nature of the state-owned enterprise, we can't simply judging its macro efficiency by margin profit ratio, instead, we should check the whether the state-owned enterprise add investment in the effective margin. Therefore, this paper used data to describe the changes of state-owned investment distribution in different industries to evaluate its industrial efficiency.

Before 1990s, the state-owned enterprises were widely distributed in various industries in China. With extended decision-making authorities, the decentralized of fixed assets investment and the multi-channel of financing, the investment of the state-own enterprise expanded sharply and scattered in various industries.

Since 1989, in China, the macroeconomic control system began to center in industrial policies, and the government levied fixed asset investment regulation tax. After 1995, the nation supported the projects in line with national industrial policies in loans, interest subsidy, bond and rate of fixed asset investment regulation tax. Therefore, since 1990s, the industrial structure adjustment of state-owned enterprise accelerated. The investment of state-owned enterprise transferred to key industries step by step and got remarkable achievements in industrial structure adjustment. The total assets of state-owned post and telecommunications industry had increased from 36.62 billion in 1990 to 1.366 trillion in the end of 2006, a 34.2 fold increase, a $32.8 \%$ annual increase rate. The development of state-owned manufacture industry became slowly gradually, the percentage of its fixed assets investment in the total state-owned investment decreased year by year, from $35 \%$ in the early 1980 to $15 \%$ in 2006. Wholesale, retail, trade and catering industries recessed obviously. From 1998 to 2006, state-owned retail industry were all negative increase, the percentage of its fixed assets investment in the total state-owned investment declined sharply.

Above all, from the industrial efficiency of the stateowned enterprise, we can get that the state-owned enterprise can obey the government policy exactly and quickly. The state-owned fixed-assets investment are centralizing to the industries involving the nation security, natural monopoly industries, the industries providing important public goods and service and the key enterprises in high-tech industries and pillar industries.

\section{2) The regional efficiency of state-owned enterprise}

In 1988, the Chinese government launched the strategy to accelerate the development of the eastern coastal areas. Then the fixed assets investment of state-owned enterprises had been mainly in the eastern coastal areas, which made the state-owned enterprises in eastern coastal areas more strong than central and western areas. The total assets owned by state-owned enterprise in eastern coastal areas were 3.3 trillion China Yuan, accounting for $65.4 \%$ of the total; the total assets in central areas were 1.1trillion China Yuan, accounting for $21.8 \%$, and the total assets in the western areas were 0.64 trillion China Yuan, accounting for $12.8 \%$. The regional distribution of state-owned enterprise were in gradient, the number of state-owned enterprise in eastern coastal areas were 594 thousand, accounting for $41.3 \%$ of the total; the central areas were 201 thousand, accounting for $34.9 \%$, and the western areas were 501 thousand, accounting for $23.8 \%$.

With the fast development in eastern areas, the regional disparities were expanding. Therefore in June 1999, the Chinese government proposed "While continuing to speed up development of east, we must lose no time to expedite the development of central and west regions". After 10 years sustained growth, in 1998, the proportion of investment of state-owned enterprises in eastern coastal regions began to decline, falling to $49 \%$ in 2002 , and this was the lowest point since 1986; meanwhile, investment of state-owned enterprises in central and western regions began to increase, the investment in central region rose from $24 \%$ in 1998 to $26.4 \%$ in 2003; compared with central region, the investment in western region increased faster, from $14.8 \%$ in 1997 to $17.6 \%$ in 2003 .

\section{THE SUGGESTIONS FOR THE IMPROVEMENT OF INVESTMENT EFFICIENCY OF STATE-OWNED ENTERPRISE IN THE FUTURE}

\section{A. Further deepen the investment system reform}

More than 30 years' reform in investment system had improved the investment efficiency of state-owned enterprises; while there still many policies to improve in investment system. The next reform should be centered on coordinated development of the regional economy, which requires appropriate investment scale and structure, especially requires more attention to structure and efficiency. 
TABLE I. THE REGIONAL DISTRIBUTION OF STATE-OWNED ENTERPRISE INVESTMENT (\%)

\begin{tabular}{|c|c|c|c|c|c|}
\hline & $\begin{array}{c}1981 \sim \\
1985\end{array}$ & $\begin{array}{c}1986 \sim \\
1990\end{array}$ & $\begin{array}{c}1991 \sim \\
1995\end{array}$ & $\begin{array}{l}1996 \sim \\
2000\end{array}$ & $\begin{array}{l}2001 \sim \\
2005\end{array}$ \\
\hline $\begin{array}{l}\text { eastern coastal } \\
\text { areas }\end{array}$ & 47.5 & 53.0 & 54.7 & 54.2 & 51.4 \\
\hline central areas & 28.5 & 25.3 & 24.3 & 24.3 & 26.1 \\
\hline western areas & 17.0 & 15.4 & 14.9 & 15.7 & 17.4 \\
\hline others & 7.0 & 6.3 & 6.1 & 5.8 & 5.1 \\
\hline
\end{tabular}

Sources: China Investment Yearbook (1950 1995), China Statistical Yearbook 1997 2006)

\section{B. Accelerate the reform of state-owned enterprise}

According to the requirement state-owned assets management system reform and modern corporate system, the state-owned enterprise should establish and improve the contributor policy in state-owned assets, to ensure the separation of ownership and management; strengthen the risk control mechanism in investment, execute the legal person responsible for projects strictly and detail rights, obligations or liabilities of the managers; establish and perfect the investment decision process and the system of assigning responsibility for major losses of state assets.

\section{REFERENCES}

[1] Sun, L. X., Estimating Investment Function Based on Co-integration: the Case of China. Journal of Comparative Economics, 1998, Vlo.26, No.1, pp. 175-191.

[2] Rawski, T. G. Will Investment Behavior Constrain China's Growth? China Economic Review, 2002, Vol.13,No.4, pp. 361-372.

[3] Liu Yuhui, the Key Crux of Investment in China is the Investment System. China financial and economic news,2007-01-30

[4] Zhang Jun, An Empirical Research on Capital Formation, Efficiency of Investment and China's Economic Growth, 2006, Tsinghua University Press

[5] Xiao Geng, the Puzzle on Rate of Capital Return in China, South Weekends, 2006.9.21.

[6] Zhang Gongfu, Wang Yongqiang, Liu Zhen, Local Protection, Corporate Investment and Corporate Competitive Advantage: Evidence from Chinese Manufacturing Listed Companies. Economic Survey.2013, No.5, pp.84-89.

[7] Zhang Guiling, The Effect Analysis of the Investment System Reform on the Investment Efficiency of State-Owned Economy, Finance and Accounting Monthly, 2010, Vol.15, pp.23-26.

[8] Zhang Gongfu, Government Intervention, Political Connections and Corporate Inefficient Investment: Empirical Research by the Panel Data from Listed Company of China,The Theory and Practice of Finance and Economics, 2011, Vol. 32, No.171, pp.24-30.

[9] Qiu Jing, Monetary Policy and Investment Efficiency of Listed Companies in China, 2014, Vol. 35, No.191, pp..34-39.

[10] Wang Yuhua, Zhao Ping, The Dynamic Relationship among Investment Scale, Investment Efficiency and Economic Growth, Economy and Management, 2013, Vol. 27, No.10, pp.45-49. 